\title{
Lung Metastasis of Malignant Melanoma with Unknown Primary Origin
}

\author{
Primeri Bilinmeyen Malign Melanomun Akciğer Metastazı
}

Haşim Boyacı,' Serap Argun Barış, Tuğba Aşlı Önyılmaz,' Kürşat Yıldız, Yusuf Taha Güllü, ilknur Başyiğit,' Füsun Yıldız'

\begin{abstract}
Malignant melanoma is a malignant tumor with increasing prevalence worldwide. However, metastatic malignant melanoma with unknown primary origin is rarely seen. The current study presents a case with bilaterally multiple nodules in pulmonary parenchyma in which no primary malignant site was found, despite detailed screening and diagnosed as metastasis of malignant melanoma by surgical lung biopsy. The current case is presented as a reminder that malignant melanoma should be kept in mind in metastatic lung lesions with unknown primary origin.
\end{abstract}

Key words: Malignant melanoma, unknown primary origin, lung, metastasis, pulmonary nodules.

\section{Özet}

Malign melanom, tüm dünyada prevalansı giderek artan bir malign tümördür. Bununla birlikte, primeri bilinmeyen metastatik malign melanom olguları nadir görülmektedir. Biz de bilateral akciğer parankiminde multipl nodülleri olan ve yapılan tarama tetkiklerinde primer odak saptanamayan ancak açık akciğer biyopsi sonucunda malign melanom metastazı tanısı konulan olgumuzu sunmaktayız. Bu olgu, primeri bilinmeyen akciğer metastazı olgularında malign melanomun da akılda tutulması gerektiğini hatırlatmak amacıyla sunulmuştur.

Anahtar Sözcükler: Malign melanom, primeri bilinmeyen, akciğer, metastaz, pulmoner nodül.

'Department of Chest Diseases, Kocaeli University Faculty of 'Kocaeli Üniversitesi Tıp Fakültesi, Göğüs Hastalıkları AnabiMedicine, Kocaeli, Turkey

${ }^{2}$ Department of Pathology, Kocaeli University Faculty of Medicine, Kocaeli, Turkey Kocaeli

Submitted (Başvuru tarihi): 06.03.2014 Accepted (Kabul tarihi): 30.04.2014

Correspondence (iletişim): Serap Argun Barıs, Department of Chest Diseases, Kocaeli University Faculty of Medicine, Kocaeli, Turkey e-mail: serapargun2002@yahoo.com 
Malignant melanoma is a malignant tumor of melanocytes. It constitutes $4 \%$ of skin cancers. It is most frequently seen between 30 and 60 years of age with no gender preference. Common sites for metastasis of malignant melanoma are regional lymph nodes, bones, and the central nervous system. Metastasis in the lungs could be found in 10-15\% of the cases during the course of the disease $(1,2)$. However, lung metastasis of malignant melanoma with unknown primary origin is quite rare. The current study presents case with multiple lung nodules that are diagnosed as metastasis of malignant melanoma by surgical lung biopsy in which no primary site of melanoma was found, despite detailed systemic examination.

\section{CASE}

A 54-year-old male patient presented with complaints of dry coughing, fatigue, and dyspnea during exercise for 3 to 4 months. The patient was a non-smoker and there was no previous history of environmental dust and/or fume exposure or regular use of medication. His medical history was unremarkable. The patient was dyspneic and cyanotic on admission. His respiratory rate was 32 breaths per minute, blood pressure was 120/70 mmHg, and heart rate was 98 beats per minute. His respiratory sounds were coarse and expiration was lengthened in the physical examination. Laboratory results were as follows: CRP: $1.34 \mathrm{mg} / \mathrm{dL}$; sedimentation rate: $15 \mathrm{~mm} / \mathrm{h}$; WBC: $8.61 \times 10^{3} \mathrm{U} / \mathrm{L}$; and $\mathrm{Hb}: 16.4 \mathrm{~g} / \mathrm{dL}$. Other biochemical markers were within normal ranges. His chest $\mathrm{x}$-ray revealed multiple micro-nodular densities in both lung areas, which was suggestive of miliary tuberculosis or metastasis (Figure 1). Diffuse nodules were observed in both lungs in the thorax CT suggesting metastasis (Figure 2). Positron emission tomography (PET-CT) was performed in order to determine the metabolic activity of detected nodules. The PET-CT showed multiple nodular densities measuring approximately $13 \mathrm{~mm}$ in size and consolidated in both lungs (SUVmax: 7.28) and with a minimal metabolic activity in the right lower paratracheal lymph node (SUVmax: 2.62). It was reported that the findings might be consistent with malignancy or infectious/inflammatory process. No endobronchial lesions were observed in the diagnostic fiber-optic bronchoscopy. A transbronchial biopsy was conducted from the basal segment of the right lower lobe and bronchial lavage was obtained from both bronchial systems. The transbronchial biopsy result was negative for granulomatous lesion and/or malignancy. The bronchial lavage was negative for acid-fast bacilli
(AFB) without any growth in non-specific and mycobacterial cultures. No malignant lesions were found in the abdominal ultrasonography (USG) and scrotal USG examinations. A transthoracic needle aspiration biopsy was performed that was reported to be "malignant nodule suggesting metastasis of papillary thyroid carcinoma" and exploration of thyroid gland was recommended. The ultrasonographic examination of the thyroid gland revealed micronodules, which are not concordant with malignancy and fine needle aspiration biopsy of the nodules were reported as normal thyroid tissue with no evidence of malignancy. The surgical lung biopsy was performed and the histopathological examination of the nodules was reported to be metastasis of malignant melanoma (Figures 3 and $4 a, b$ ). Tumor cells had positive immune reactions for $\mathrm{S} 100$ protein, HMB45, and Melan A. When the patient's history was reassessed, it was revealed that he had a lesion in the scalp seven years ago; the lesion had been excised and the pathological assessment was reported as benign. Following open lung biopsy, the patient underwent dermatologic and ophthalmologic examination for malignant melanoma and no primary origin for melanoma was detected. The patient was scheduled for colonoscopy, but the procedure was cancelled due to admission to the intensive care unit with respiratory failure on postoperative day 2 . The noninvasive mechanic ventilation was performed in the intensive care unit. The patient was transferred to another health care center at his own request, in which his medical treatment was planned; however, the patient died 1.5 months following the diagnosis.

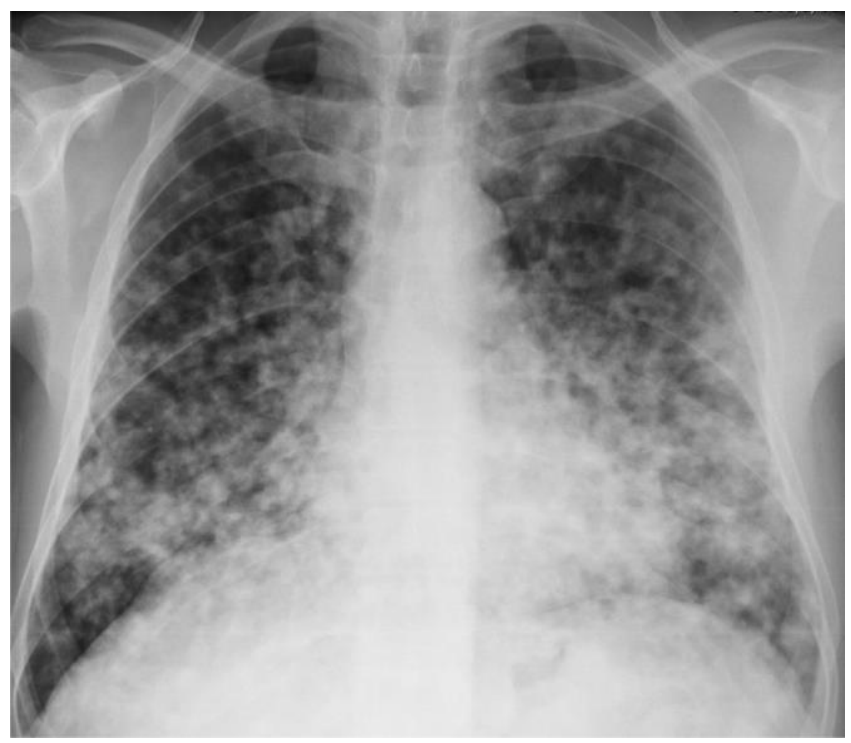

Figure 1: Bilateral diffuse nodular opacities on chest radiography 


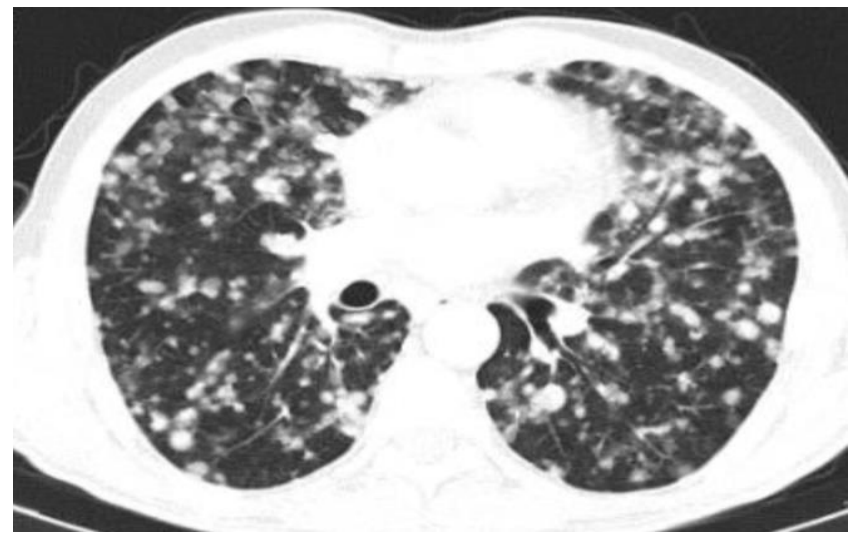

Figure 2: Bilateral diffuse metastatic nodules in the thorax CT

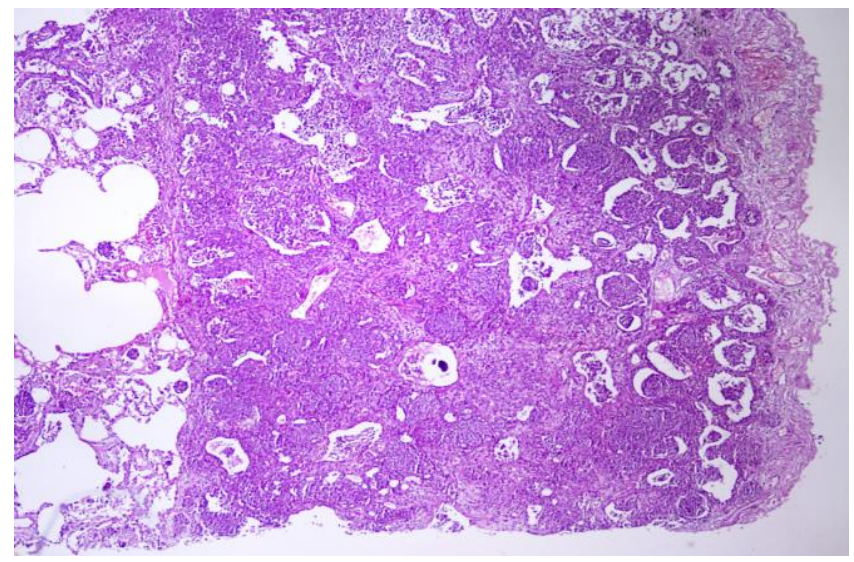

Figure 3: Tumor cells that include nodular infiltrates were observed in the lung. Tumor cells consisted of clusters forming eddies in intraalveolar and interstitial area (H-E x 40)

\section{DISCUSSION}

Malignant melanoma is an aggressive tumor that is rarely observed among skin cancers. Malignant melanoma cases with unknown primary origin are rarely seen, constituting $2-6 \%$ of all malignant melanoma cases (3-5). In the study conducted by de Waal et al. (4), the primary origin was reported to be unknown in 857 (2.6\%) of 33,181 melanoma patients monitored between 2003 and 2009. This ratio is similar to that reported in the study by Katz et al. (5), in which visceral metastasis was detected in 23 of 65 melanoma cases with unknown primary origin.

There may be various reasons for not being able to detect the primary tumor in malignant melanoma cases diagnosed with metastasis. These reasons include the complete disappearance of primary melanoma after metastasis; primary melanoma directly originating from ectopic melanocytes in lymph nodes; or the primary tumor's location in anatomic sites that are difficult to access (6). In order to establish the diagnosis of patients with malignant melanoma of unknown primary origin, the patient is required to meet to following criteria: the absence of any abnormality in the eye, rectum, or vulva in the physical examination; the absence of a history of orbital enucleation or exenteration; absence of a history of cauterization or surgery due to nevus, birthmark, chronic paronychia, or skin scars; and no previous local intervention in the skin area of lymph drainage where metastatic melanoma was detected (7). When the current patient's background was reassessed after his pathological diagnosis, it was found that a lesion from the scalp was excised, but was concluded to be benign. In addition, the results of his ophthalmologic examination and all extrapulmonary system screenings were within normal limits.

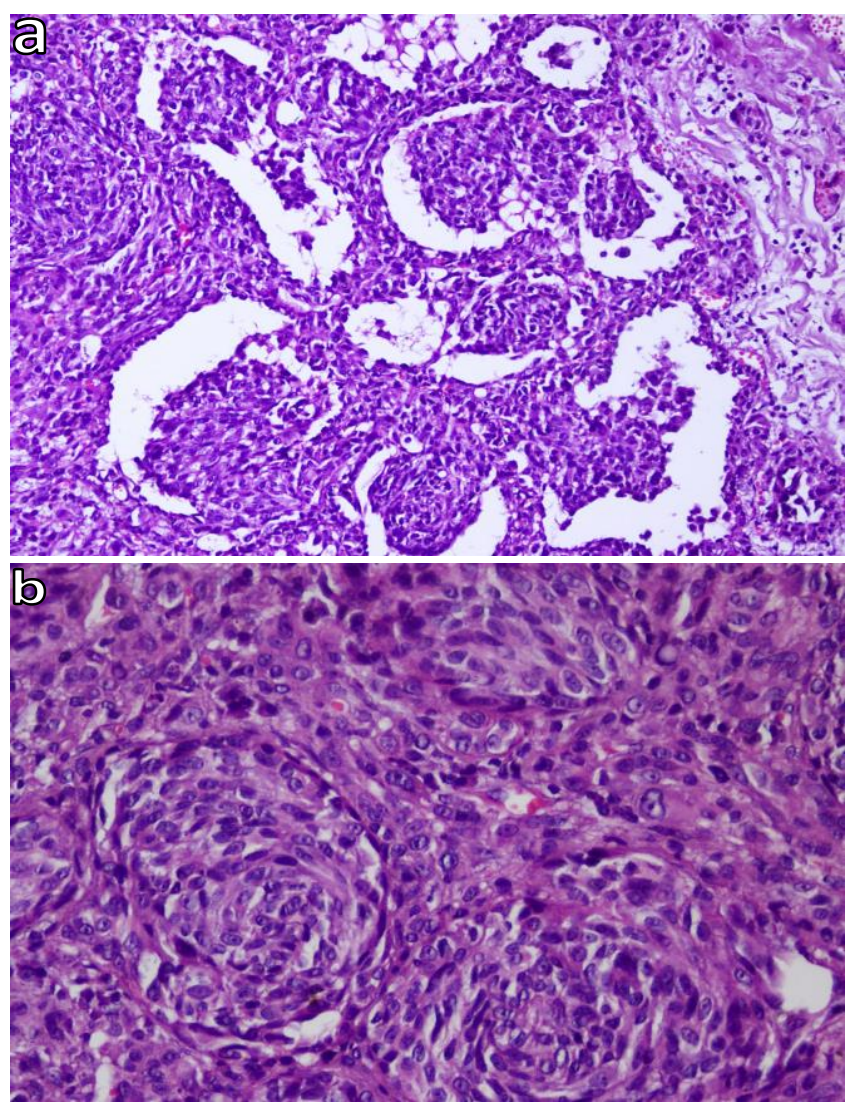

Figure 4a, b: Tumor cells with round or spindle-shaped core and medium width cytoplasm (H-E x 200)

Thoracic metastases of malignant melanoma vary to a great extent $(1,8)$. In the radiological assessment performed by Chen et al. (1) on 130 cases of malignant melanoma with thorax metastasis, it was found that 52 of the cases had multiple nodules, 26 had solitary nodules, two had miliary pattern, nine had hilar and/or mediastinal lymphadenopathies, three had pleural effusion, one had a lytic bone lesion, one had an extrapleural mass, and 36 had combined lesions. In addition, multiple pulmonary nodules were detected in $98 \%$ of the cases in another study that assessed 84 cases with metastatic 
malignant melanoma (8). These previous case series demonstrated that multiple lung nodules are the most frequent radiological finding in metastatic melanoma. The current patient also presented with bilateral multiple lung nodules that were suggestive of metastasis. These findings suggested that metastatic melanoma should be considered, especially in patients who had a radiological appearance of metastasis without symptoms of extrapulmonary organs and/or systems, since the primary origin of melanomas could be in an anatomic site that is difficult to access and/or unable to generate any symptoms. The five-year survival rate of malignant melanoma with lung metastasis is $4 \%(9)$. It is suggested that radiological appearance affects survival while solitary metastasis have the best survival rates; however, prognosis is worse in cases with miliary metastasis and bone destruction (1). In another study, snowstorm multiple metastases have been suggested to have the worst prognosis compared to other pulmonary involvements (10). The present patient also had multiple snowstorm involvement, as could be seen in the chest radiograph, which is thought to be associated with a poor prognosis.

In conclusion, cases with malignant melanoma should have radiological monitoring for lung metastasis, and malignant melanoma should be kept in mind in lung metastases with unknown primary origin.

\section{CONFLICTS OF INTEREST}

None declared.

\section{AUTHOR CONTRIBUTIONS}

Concept - H.B., S.A.B., T.A.Ö., K.Y., Y.T.G., I.B., F.Y.; Planning and Design - H.B., S.A.B., T.A.Ö., K.Y., Y.T.G., I.B., F.Y.; Supervision - H.B., S.A.B., T.A.Ö., K.Y., Y.T.G., I.B., F.Y.; Funding - H.B., F.Y.; Materials - H.B., Y.T.G.; Data Collection and/or Processing - Y.T.G., S.A.B., K.Y.; Analysis and/or Interpretation - H.B., S.A.B., K.Y.; Literature Review - T.A.Ö., S.A.B.; Writing - S.A.B., I.B.; Critical Review - I.B., F.Y.

\section{YAZAR KATKILARI}

Fikir - H.B., S.A.B., T.A.Ö., K.Y., Y.T.G., İ.B., F.Y.; Tasarım ve Dizayn - H.B., S.A.B., T.A.Ö., K.Y., Y.T.G., I.B.,
F.Y.; Denetleme - H.B., S.A.B., T.A.Ö., K.Y., Y.T.G., I.B., F.Y.; Kaynaklar - H.B., F.Y.; Malzemeler - H.B., Y.T.G.; Veri Toplama ve/veya İşleme - Y.T.G., S.A.B., K.Y.; Analiz ve/veya Yorum - H.B., S.A.B., K.Y.; Literatür Taraması T.A.Ö., S.A.B.; Yazıyı Yazan - S.A.B., İ.B.; Eleştirel İnceleme - I.B., F.Y.

\section{REFERENCES}

1. Chen JT, Dahmash NS, Ravin CE, Heaston DK, Putman $\mathrm{CE}$, Seiger HF, et al. Metastatic melanoma in the thorax: report of 130 patients. AJR Am J Roentgenol 1981; 137:293-8. [CrossRef]

2. Dasgupta T, Brasfield R. Metastatic melanoma; a clinicopathological study. Cancer 1964; 17:1323-39.

3. Guiliano AE, Moseley HS, Morton DL. Clinical aspects of unknown primary melanoma. Ann Surg 1980; 191:98104. [CrossRef]

4. de Waal AC, Aben KK, van Rossum MM, Kiemeney LA. Melanoma of unknown primary origin: a populationbased study in the Netherlands. Eur J Cancer 2013; 49:676-83. [CrossRef]

5. Katz KA, Jonasch E, Hodi FS, Soiffer R, Kwitkiwski K, Sober AJ, et al. Melanoma of unknown primary: experience at Massachusetts General Hospital and Dana-Farber Cancer Institute. Melanoma Res 2005; 15:77-82.

6. Chorost MI, McKinley B, Tschoi M, Ghosh BC. The management of the unknown primary. J Am Coll Surg 2001; 193:666-77.

7. Dasgupta T, Bowden L, Berg JW. Malignant melanoma of unknown primary origin. Surg Gynecol Obstet 1963; 117:341-5.

8. Dwyer AJ, Reichert CM, Woltering EA, Flye MW. Diffuse pulmonary metastasis in melanoma: radiographicpathologic correlation. AJR Am J Roentgenol 1984; 143:983-4. [CrossRef]

9. Harpole DH, Johnson CM, Wolfe WG, George SL, Seigler HF. Analysis of 945 cases of pulmonary metastatic melanoma. J Thorac Cardiovasc Surg 1992; 103:74850 .

10. Webb WR, Gamsu G. Thoracic metastasis in malignant melanoma. A radiographic survey of 65 patients. Chest 1977; 71:176-81. [CrossRef] 